\title{
Impact of Lean Manufacturing Practices on Operational and Business Performance: Evidence from Sri Lankan Food Industry
}

Sri Lanka Journal of Social Sciences and Humanities Volume 1 Issue 2, August 2021: 69-76 ISSN: 2773 692X (Online), 27736911 (Print) Copyright: (C) 2021 The Author(s)

Published by Faculty of Social Sciences and Languages, Sabaragamuwa University of Sri Lanka Website: https://www.sab.ac.lk/sljssh DOI: http://doi.org/10.4038/sljssh.v1i2.39

\author{
Silva, C.W.C. ${ }^{1,{ }^{*}}$ and Warnapura, H.H.S.C. ${ }^{1}$ \\ ${ }^{1}$ Department of Decision Sciences, University of Sri Jayewardenepura, Sri Lanka.
}

Received: 09 December, 2020, Revised: 06 March, 2021, Accepted: 04 May, 2021.

How to Cite this Article: Silva, C.W.C. and Warnapura, H.H.S.C. (2021). Impact of lean manufacturing practices on operational and business performance: Evidence from Sri Lankan food industry. Sri Lanka Journal of Social Sciences and Humanities, 1(2), 69-76.

\begin{abstract}
Lean is a strategy that aims to achieve smooth production flow by eliminating waste and hence helps manufacturing firms realize their time, cost, and quality goals. Food manufacturers not only have limited ability to offer uniform quality but also a greater chance of generating wastes due to the perishable nature of materials. This study investigates the degree to which the Sri Lankan food sector is practicing lean manufacturing and examines the direct and indirect relationships between lean manufacturing, business performance, and operational performance. Data were collected through a questionnaire distributed to managers who have lean experience in the food industry. Using a sample of 86 , the hypotheses were tested applying Partial Least Square Structural Equation Modelling with SmartPLS software. Developing a new construct to represent four lean manufacturing practices, namely, Just-intime (JIT), Total Quality Management (TQM), Total Preventive Maintenance (TPM), and Human Resource Management (HRM), this study empirically confirms that lean manufacturing has a significant positive impact on both operational and business performance. Furthermore, operational performance partially mediates the relationship between lean manufacturing and business performance. The findings offer valuable implications for mangers, particularly in the food industry to achieve sustainability through practicing lean in their manufacturing and supply chain operations.
\end{abstract}

Keywords: Business performance, food industry, lean manufacturing, operational performance, Sri Lanka

\section{INTRODUCTION}

With the introduction of mass production, various approaches have been introduced by companies for several decades, to increase quality and productivity in manufacturing operations. Waste of material, space, time and other resources is one of the biggest challenges in the manufacturing sector when achieving high quality and increased productivity. Lean manufacturing (LM) is a strategy that aims to achieve smooth production flow by eliminating waste and increasing the activities that create value (Bevilacqua, Ciarapica, \& De Sanctis, 2017; Nordin, Deros, \& Wahab, 2010). Just-in-time (JIT), Total Quality Management (TQM), Total Preventive Maintenance (TPM), and Human Resource Management (HRM) are the most commonly used lean practices in firms and therefore, have been addressed in several studies (e.g. Dal Pont, Furlan, \& Vinelli, 2008; Dora, Van Goubergen, Kumar, Molnar, \& Gellynck, 2014; Hernandez-Matias, Ocampo, Hidalgo, \& Vizan, 2019; Nordin et al., 2010). Practicing lean helps organizations to achieve sustainability as waste elimination provides economic, social as well as environmental advantages. Therefore, lean manufacturing practices enable companies to improve performance at the operational level by reducing inventories, costs and increasing quality, productivity, and speed, as well as at the business level by increasing sales, profits and customer satisfaction.
Food is an industry that handles raw materials, semi-finished and finished products that are perishable and largely variable in quality and manufacturing lead times thereby has a number of ways and supply chain points of generating and accumulating wastes. In addition, the highly unpredictable supply of raw materials is a common feature in food sector (Dora et al., 2014). Therefore, practicing lean, which focuses on reducing waste would be critical for food manufacturing companies. Currently, many large food manufacturing companies in Sri Lanka are practicing lean to compete with global trends. However, the extent to which these companies adopt different lean practices and the contribution of these practices for their business success is unrevealed. Therefore, evaluating the extent of lean implementation and understanding its effectiveness in this unique industry is extremely valuable.

While the empirical evidence from the Sri Lankan food industry is limited, there found a few studies conducted in other countries on the extent of lean implementation in various industries, (e.g. Amos, Ariguzo, Egwakhe, \& Abiodun, 2020; Bhutta, Egilmez, Chatha, \& Huq, 2017; Nawanir, Lim, \& Othman, 2016; Nordin et al., 2010; Perera \& Kulasooriya, 2011; Wickramasinghe \& Wickramasinghe, 2017). According to Nawanir, Kong Teong, and Norezam Othman (2013), lean manufacturing practices significantly improve business performance (BP), and operational performance (OP) partially

\footnotetext{
* Corresponding author: Tel.: +94(71)4463955; Email: chathurani@sjp.ac.lk iD https://orcid.org/0000-0001-9529-0028
} 
mediates this relationship. However, the effects of individual lean practices such as just-in-time, total quality management, total preventive maintenance, human resource management (or employee involvement) on different dimensions of operational and business performance have not been empirically confirmed with the evidence from Sri Lankan food manufacturing sector.

Addressing the gaps highlighted above, this study aims to understand the degree of lean implementation in Sri Lankan food industry and to examine the impact of lean manufacturing practices on operational and business performance, by using a more informative measurements for lean manufacturing practices. Furthermore, this study investigates whether operational performance mediates the relationship between lean manufacturing practices and business performance.

The following section reviews the literature leading to the development of hypotheses concerning the direct and indirect impact of lean manufacturing practices on business performance, through operational performance.

\section{THEORETICAL BACKGROUND AND HYPOTHESES}

Studies have suggested a positive impact of lean manufacturing on business performance dimensions such as profitability and market success (Nawanir et al., 2016; Yang, Hong, \& Modi, 2011). Lean practices enable companies to offer low prices to the customers without compromising quality, through the elimination of waste (Bhamu \& Singh Sangwan, 2014; Chauhan \& Singh, 2012). Total preventive maintenance and total quality management are the major lean manufacturing practices that help in this. Regular inspection of machines, prevention of breakdowns, and continuous improvement ensures delivering customer expected quality with a little or no addition to costs and prices. This leads to increased sales and greater customer satisfaction (Nawanir et al., 2013; Nawanir et al., 2016) perhaps due to the fact that the price is undoubtedly the prime concern of many customers. Facilitating pull production enabled by JIT strategy, quality management, and employee involvement in lean implementations help manufacturing firms to achieve higher levels of market and financial performance (Yang et al., 2011). However, the existing literature evidence is mainly for industries other than food manufacturing where the waste elimination or lean is much more critical. Therefore, the following hypothesis is tested with data gathered from Sri Lankan food industry:

H1: Lean manufacturing practices have a positive direct impact on business performance.

Implementation of lean manufacturing practices is believed to have a positive impact on operational performance in terms of low cost, high quality, productivity, flexibility, and fast delivery (Chavez, Gimenez, Fynes, Wiengarten, \& Yu, 2013; Nawanir et al., 2013). Implementation of lean practices throughout the production processes helps organizations to reduce cost in different ways. For example, practicing strategies such as JIT not only minimizes inventories but also ensures the delivery of products at the time that customer actually needs them (Rahman, Laosirihongthong, \& Sohal, 2010). Adhering to the TQM practices such as continuous improvement and quality control reduces quality problems and adds value to the products. Companies can avoid sudden machine breakdowns from the implementation of total preventive maintenance, which leads to reduced maintenance costs. Lean practices related to human re- sources leads to significant increases in operational performance in terms of waste reduction and flexibility (Hernandez-Matias et al., 2019). Greater employee involvement and empowerment represents essential HRM elements in achieving these performance improvements. In a study based on the textile industry in Sri Lanka, Wickramasinghe and Wickramasinghe (2017) have found a positive impact of lean manufacturing practices on manufacturing performance. In order to support this literature with evidence from the Sri Lankan food industry, the following hypothesis is tested:

H2: Lean manufacturing practices have a positive direct impact on operational performance.

As discussed above, lean manufacturing practices can directly improve the operational and business performance of firms. In addition, lean manufacturing practices can improve business performance indirectly through operational performance which acts as a mediator (Nawanir et al., 2013). Reduction of waste and non-value-added activities leads to lower costs and higher quality in manufacturing operations, and hence ensures a great market success. In the same way, preventive maintenance of fixed manufacturing assets helps in reaching higher levels of business performance (Nawanir et al., 2016). Moreover, close relationships with suppliers and on time delivery of materials are important factors for improving customer satisfaction, sales, and profits (White \& Pearson, 2001). Encouraging employee suggestions and empowering people involved in operations will improve innovativeness, quality, productivity, and flexibility in production systems while reducing waste (Ripley \& Ripley, 1992). However, the empirical evidence for the mediating role of operational performance in the association between lean manufacturing practices including JIT, TPM, TQM, and HRM and business performance from Sri Lankan context is almost lacking in the literature. Therefore, by examining the following hypothesis, this study aims to establish the mediating effect of operational performance on the relationship between lean manufacturing practices and business performance, for the Sri Lankan food manufacturing sector:

H3: Operational performance mediates the relationship between lean manufacturing practices and business performance.

Based on the above reviews of literature leading to the hypotheses $\mathrm{H} 1, \mathrm{H} 2$, and $\mathrm{H} 3$, this research proposes the direct impact of Lean Manufacturing on Operational Performance and Business Performance, as well as Operational Performance as a mediator to the relationship between Lean Manufacturing and Business Performance. Since the impact of different lean practices on various dimensions of operational and business performance has not been sufficiently explored particularly for the food sector, this study conceptualizes a comprehensive model including all important dimensions of lean manufacturing as well as performance indicators.

Just in time (JIT) is a common lean strategy used by companies to decrease waste by receiving goods only when they are needed. Prior investigations on lean effectiveness have largely incorporated this concept as it is a major factor for reducing inventory holding costs (Chavez et al., 2013; Nawanir et al., 2013; Yang et al., 2011). Total preventive maintenance (TPM) which encourages everyone's participation in the maintenance of machines and equipment has also been addressed in several lean studies as a concept of saving time and costs through fewer breakdowns (Nawanir 
et al., 2013). Quality management or TQM is another important aspect of lean manufacturing, which represents a set of interrelated initiatives to assure the quality of the products and the equipment used to manufacture them (Yang et al., 2011). The human resource aspect of lean has been largely addressed in earlier research as employee involvement and empowerment are essential elements of successful lean implementation (Dal Pont et al., 2008; Hernandez-Matias et al., 2019; Yang et al., 2011).
In order to test the hypotheses stated above, this study adopted the four concepts JIT, TQM, TPM, and HRM to measure the overall lean manufacturing construct. The measurements scales for operational performance and business performance were adopted from Nawanir et al. (2013). Accordingly, operational performance is represented by five indicators, namely, Quality, Inventory minimization, Delivery, Productivity, and Cost reduction. Business performance in terms of Profitability, Sales, and Customer satisfaction is the main dependent construct in this model. Figure 1 presents the conceptual model developed for the study.

Figure 1: Conceptual research model

- Quality

- Inventory minimization

- Delivery

- Productivity

- Cost reduction

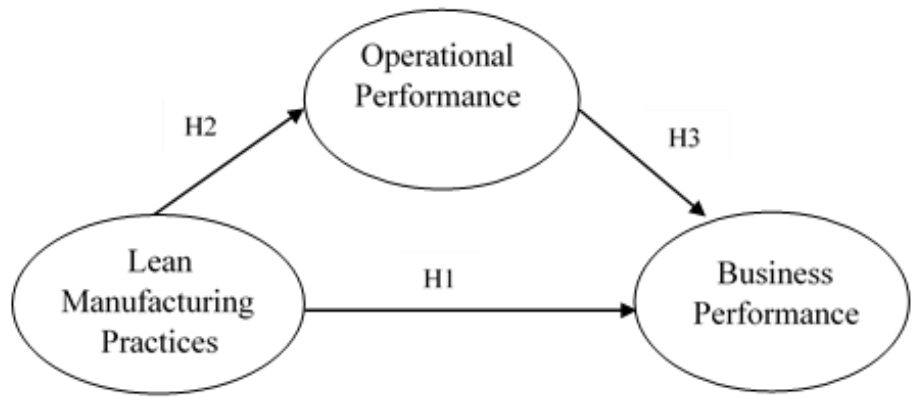

- Just in Time

- Total Quality Management

- Total Preventive Maintenance

- Human Resource Management

\section{METHODOLOGY}

This section gives full details about the methodologies followed in the study for sample selection, data collection, data analysis, and validity and reliability assessments of the model constructs.

\section{Data and measures}

A survey was carried out for large-scale food manufacturing companies in Sri Lanka that practice lean manufacturing. According to the industry capability report (2017) produced by the Export Development Board, there were 30 key food manufacturing companies in Sri Lanka. Ten of these companies were selected randomly for the sample and they were contacted through telephone calls and e-mails requesting permission to collect data. Only nine companies that gave permission were selected to send the survey. The respondents were the managers chosen from these companies and they had been directly involved in practicing lean in their firms. Primary data were collected through a questionnaire distributed in both printed and online formats.

The questionnaire contained 52 seven-point Likert scale questions for the main constructs in the conceptual research model (Figure 1). The scale was from 1 (strongly disagree) to 7 (strongly agree) where the middle point 4 represented average opinion (neither agree nor disagree). The questionnaires were collected at several attempts. After one week of the first-time distribution of the printed questionnaire, the respondents were reminded through telephone calls, and an e-mail reminder was sent to the online respondents. A total of 86 questionnaires was completed and returned where the pre-calculated minimum sample size requirement for achieving $80 \%$ statistical power, assuming a medium effect of the independent variables was 76 . This led to a $100 \%$ response rate of printed questionnaires where 40 questionnaires were distributed. 126 online questionnaires were sent, and its response rate was only $37 \%$.

A descriptive statistical analysis and a correlation analysis were performed using the SPSS software. Descriptive statistical measures such as mean and standard deviation and suitable graphical tools were used to explore the extent to which lean is practiced in the selected firms. Partial Least Square Structural Equation Modelling (PLS-SEM) using SmartPLS software was performed to test the hypothesized relationships in the conceptual research model. Multi-item scales were used for the three second-order constructs: lean manufacturing practices, operational performance, and business performance. Four lean manufacturing constructs (JIT, TQM, TPM, and HRM), four operational performance constructs (Quality, Delivery, Inventory Minimization, Productivity), and three business performance constructs (Profit, Sales, and Customer Satisfaction) were included in the structural model. The operationalisation of all the model constructs is given in the Appendix.

\section{MEASUREMENT MODEL EVALUATION}

Internal consistency reliability of the measured constructs was evaluated using the composite reliability. The values corresponding to all the first-order constructs are given in Table 1 . Initially, some composite reliability values of the constructs were lower than the minimum satisfactory level 
(0.7). Then the measurement items that had low loadings were removed and after removing these items, the level of internal consistency was adequately confirmed. Construct validity was established through convergent validity and discriminant validity. Convergent validity refers to the degree to which individual items in a questionnaire measure the same underlying construct, which can be evaluated using Average Variance Extracted (AVE), The AVE of each construct should be higher than 0.5 to confirm convergent validity of the construct (Hair et al, 2011). Table 1 also presents the results of the convergent validity assessment.

Table 1. Reliability and convergent validity assessment

\begin{tabular}{lrr}
\hline Construct & Composite Reliability & AVE \\
\hline Just in Time & 0.730 & 0.585 \\
Total Quality management & 0.771 & 0.530 \\
Total Preventive Maintenance & 0.854 & 0.596 \\
Human Resources Management & 0.782 & 0.563 \\
Quality & 0.876 & 0.590 \\
Inventory Minimization & 0.862 & 0.612 \\
Delivery & 0.935 & 0.878 \\
Productivity & 0.897 & 0.814 \\
Cost Reduction & 0.823 & 0.609 \\
Profit & 0.793 & 0.491 \\
Sales & 1.000 & 1.000 \\
Customer Satisfaction & 0742 & 0.496 \\
\hline
\end{tabular}

Source: Survey

Discriminant validity measures the extent to which the individual items intended to measure one latent construct do not at the same time measure a different latent construct. Discriminant validity was tested through inter-factor correlations. According to Hair, Ringle, and Sarstedt (2011), in order to confirm discriminant validity, the AVE of each latent construct should be higher than the construct's highest squared correlation with any other latent construct (FornellLarcker criterion) and an indicator's loadings should be higher than all of its cross-loadings. The latter criterion was satisfied and Table 2 gives the Fornell-Larcker assessment results which also indicate that there is no violation of discriminant validity.

Table 2. Discriminant validity assessment

\begin{tabular}{|c|c|c|c|c|c|c|c|c|c|c|c|c|}
\hline & COST & CS & DEL & HRM & IM & JIT & PROD & PROF & QUAL & SALE & TPM & TQM \\
\hline COST & 0.780 & & & & & & & & & & & \\
\hline CS & 0.516 & 0.705 & & & & & & & & & & \\
\hline DEL & 0.338 & 0.402 & 0.937 & & & & & & & & & \\
\hline HRM & 0.463 & 0.465 & 0.326 & 0.750 & & & & & & & & \\
\hline IM & 0.551 & 0.518 & 0.511 & 0.680 & 0.782 & & & & & & & \\
\hline JIT & 0.568 & 0.496 & 0.278 & 0.260 & 0.339 & 0.765 & & & & & & \\
\hline PROD & 0.307 & 0.452 & 0.254 & 0.364 & 0.454 & 0.277 & 0.902 & & & & & \\
\hline PROF & 0.646 & 0.541 & 0.280 & 0.266 & 0.382 & 0.523 & 0.304 & 0.700 & & & & \\
\hline QUAL & 0.584 & 0.653 & 0.368 & 0.677 & 0.573 & 0.550 & 0.536 & 0.664 & 0.768 & & & \\
\hline SALE & 0.374 & 0.499 & 0.115 & 0.291 & 0.301 & 0.283 & 0.145 & 0.493 & 0.387 & 0.594 & & \\
\hline TPM & 0.628 & 0.644 & 0.321 & 0.659 & 0.546 & 0.390 & 0.402 & 0.541 & 0.623 & 0.502 & 0.772 & \\
\hline TQM & 0.428 & 0.322 & 0.163 & 0.179 & 0.304 & 0.597 & 0.389 & 0.384 & 0.375 & 0.199 & 0.492 & 0.738 \\
\hline
\end{tabular}

Note: Diagonal values represent the AVE whereas the cell values are the squared correlations between first-order latent constructs.

\section{RESULTS AND DISCUSSION}

The analysis of the sample composition revealed that a majority of the respondents were involved in operations, supply chain, manufacturing and inventory management areas (59 out of 86 ) where lean manufacturing practices are extremely exercised. The work experience of a majority of the respondents (approximately 60\%) was 5-15 years.

Lean manufacturing practices in food industry
Table 3 gives the descriptive statistics of all the first-order constructs in the model and the Pearson's correlation coefficient values between these constructs. All four lean manufacturing practices have an average above 5 indicating a relatively higher level of lean practice in Sri Lankan food manufacturing firms. It also indicates that TQM and TPM are the most common lean manufacturing practices in these firms. This result is different from what found in the study conducted in Malaysian Automotive industry (Nordin et al. 2010) where HRM and manufacturing planning and control including JIT are the mostly adopted lean practices. These 
findings significantly add to the current literature on similar surveys in other Asian countries (e.g. Nordin et al., 2010).

The results of the correlation analysis reveal that quality, inventory minimization, and cost reduction are the main outcomes that are achieved through lean manufacturing practices. Higher correlation values of quality and cost reduction with TPM and HRM indicate the importance of total quality management and human resource management for reducing costs and improving quality. In addition, TQM practices seem to have significant effects on operational performance dimensions such as quality and cost. The effects of the above three lean manufacturing practices on business performance are also evident where JIT has no significant effect on many of the operational performance and business performance dimensions. However, significant positive correlations between lean manufacturing practices and customer satisfaction indicate the importance of all the lean manufacturing practices in improving customer satisfaction. Quality and cost reduction seem to have significantly high positive effects on profits.

Table 3: Descriptive statistics and correlations

\begin{tabular}{|c|c|c|c|c|c|c|c|c|c|c|c|c|c|c|}
\hline & Mean & SD & JIT & TQM & TPM & HRM & QUAL & $\mathrm{IM}$ & $\mathrm{DEL}$ & PROD & COST & PROF & SALE & CS \\
\hline & 5.306 & 0.527 & 1 & & & & & & & & & & & \\
\hline JIT & & & & & & & & & & & & & & \\
\hline TQM & 5.624 & 0.404 & $0.304^{* *}$ & 1 & & & & & & & & & & \\
\hline TPM & 5.788 & 0.674 & -0.043 & $0.389^{* *}$ & 1 & & & & & & & & & \\
\hline HRM & 5.344 & 0.655 & 0.057 & 0.075 & $0.542 * *$ & 1 & & & & & & & & \\
\hline QUAL & 6.019 & 0.604 & 0.187 & $0.286^{* *}$ & $0.641^{* *}$ & $0.633^{* *}$ & 1 & & & & & & & \\
\hline IM & 5.660 & 0.763 & 0.074 & 0.097 & $0.501^{* *}$ & $0.524^{* *}$ & $0.578^{* *}$ & 1 & & & & & & \\
\hline DEL & 6.066 & 0.660 & 0.062 & 0.008 & 0.146 & 0.038 & 0.107 & $0.370^{* *}$ & 1 & & & & & \\
\hline PROD & 5.724 & 0.620 & 0.127 & -0.020 & 0.209 & $0.256^{*}$ & $0.523^{* *}$ & $0.532^{* *}$ & $0.249^{*}$ & 1 & & & & \\
\hline COST & 5.750 & 0.603 & 0.198 & $0.304^{* *}$ & $0.624^{* *}$ & $0.449 * *$ & $0.571^{* *}$ & $0.529^{* *}$ & 0.160 & $0.262^{*}$ & 1 & & & \\
\hline PROF & 6.009 & 0.673 & 0.139 & $0.381^{* *}$ & $0.617^{* *}$ & $0.252^{*}$ & $0.631^{* *}$ & $0.328^{* *}$ & 0.021 & $0.346^{* *}$ & $0.649^{* *}$ & 1 & & \\
\hline SALE & 6.698 & 0.314 & -0.169 & 0.119 & $0.365^{* *}$ & 0.199 & $0.325^{* *}$ & $0.245^{*}$ & -0.086 & $0.262^{*}$ & -0.083 & 0.096 & 1 & \\
\hline $\mathrm{CS}$ & 6.302 & 0.452 & $0.302^{* *}$ & 0.125 & $0.457^{* *}$ & $0.385^{* *}$ & $0.573^{* *}$ & $0.321^{* *}$ & 0.097 & $0.401^{* *}$ & $0.434^{* *}$ & $0.551^{* *}$ & 0.196 & 1 \\
\hline
\end{tabular}

Source: Survey

Having larger average values for all the variables than the centre value will not have any serious effect on the results of the analysis because the PLS-SEM method does not have any distributional assumptions and more than $80 \%$ of indicator variables had relatively low skewness coefficients. In addition, all the standard deviation values are larger than zero indicating sufficient variability in data. Figure 2 shows the path diagram including all the model constructs.

\section{Impact of lean manufacturing practices}

Figure 2: Path model $(* p$-value $<0.01)$.

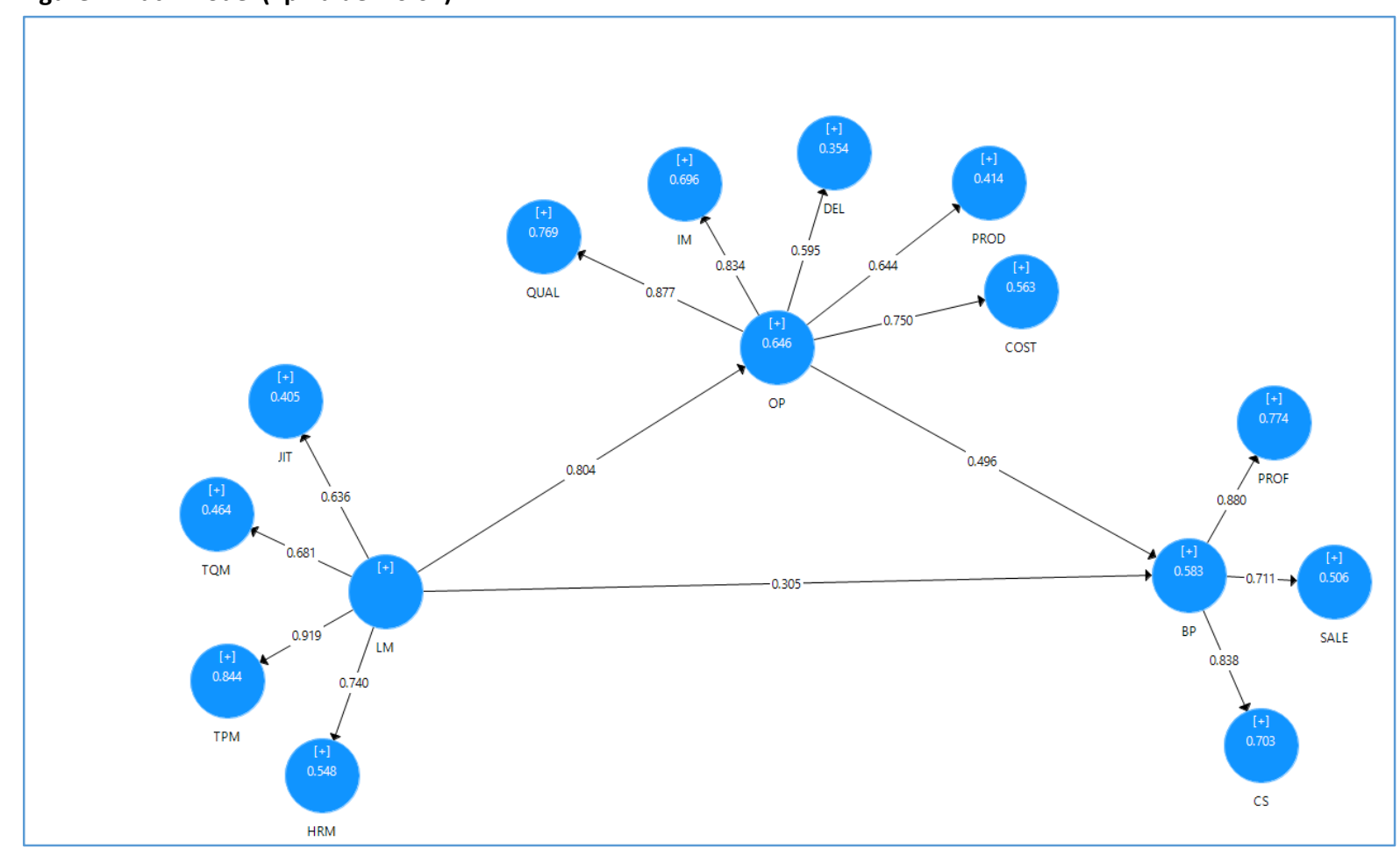


According to the results shown in Figure 2, all the path coefficients are positive and significant at a $1 \%$ level. Table 4 gives the detailed bootstrapping result related to all the direct and indirect effects hypothesised. The direct effect of lean manufacturing on business performance in the model without the mediator was 0.705 , and it was significant at a $1 \%$ level. After including the mediator, the direct path coefficient has been reduced to 0.310 while leaving both direct and indirect paths significant at a $1 \%$ level. This result implies that operational performance partially mediates the Table 4: Results of the hypothesis tests

\begin{tabular}{llll}
\hline Path & Direct effect & Indirect effect & Hypothesis supported \\
\hline LM $\rightarrow$ BP & $0.310^{*}$ & $0.389^{*}$ & $\mathrm{H} 1$ and $\mathrm{H} 3$ \\
LM $\rightarrow$ OP & $0.804^{*}$ & & $\mathrm{H} 2$ \\
$\mathrm{OP} \rightarrow$ BP & $0.484^{*}$ & $\mathrm{H} 3$ \\
\hline
\end{tabular}

$\left({ }^{*} \mathrm{p}\right.$ value $\left.<0.01\right)$

Table 5: Effects of LM practices on operational and business performance dimensions

\begin{tabular}{ll}
\hline Path & Effect \\
\hline LM $\rightarrow$ Quality & $0.705^{*}$ \\
LM $\rightarrow$ Inventory minimization & $0.671^{*}$ \\
LM $\rightarrow$ Delivery & $0.479^{*}$ \\
LM $\rightarrow$ Productivity & $0.517^{*}$ \\
LM $\rightarrow$ Cost reduction & $0.604^{*}$ \\
LM $\rightarrow$ Profitability & $0.617^{*}$ \\
LM $\rightarrow$ Sales & $0.504^{*}$ \\
LM $\rightarrow$ Customer Satisfaction & $0.581^{*}$ \\
\hline
\end{tabular}

$(* p$ value $<0.01)$

Table 5 gives the bootstrapping results on the effects of lean manufacturing practices on individual performance dimensions. All the effects are significant at a $1 \%$ level indicating that lean manufacturing practices significantly improve all aspects of operational and business performance. The results further reveal that the effects on operational performance outcomes, namely, quality, inventory minimization, and cost reduction and business performance in terms of profitability are relatively higher than the effects on other performance aspects. The minimum effect of lean manufacturing practices was observed on delivery performance.

The results of this study reveal that more established lean implementation would lead to better operational performance. This supports the findings of Nawanir et al. (2013) on manufacturing firms in Indonesia with strong empirical evidence from the Sri Lankan food industry. The findings lead to a conclusion that lean manufacturing practices contribute significantly to all the measures of business performance. This research strongly agrees with Singh, Meena, and Panwar (2016) who confirmed the impact of lean manufacturing on profitability and customer satisfaction.

\section{Evaluation of the structural model}

The proportion of explained variation of the endogenous latent variables is denoted by the $\mathrm{R}^{2}$ and is used as the main criteria for assessing the adequacy of a structural model. The values of $0.25,0.50$, or 0.75 are known to indicate weak, moderate, or substantial relationships respectively (Hair et al., 2011). The $R^{2}$ values observed for operational performance and business performance constructs are $64.7 \%$ and $58.3 \%$ respectively (Figure 2 ). In addition, the construct cross-validated redundancy $\left(\mathrm{Q}^{2}\right)$ was obtained for the two main endogenous variables, operational performance and business performance and the respective values were 0.222 relationship between lean manufacturing practices and business performance. Furthermore, the direct and indirect path coefficients suggest that the impact of lean manufacturing practices on operational performance is larger than its effect on business performance, and the indirect effect of lean manufacturing on business performance through operational performance is higher than the respective direct effect.

and 0.156 . All these results imply a moderate level of relevance and accuracy of predicting operational and business performance using the second-order construct of lean manufacturing based on the four practices, namely, JIT, TQM, TPM, and HRM.

\section{CONCLUSION}

This study was conducted to understand the extent to which Sri Lankan Food manufacturing companies have implemented lean manufacturing practices and to examine the effect of these practices on operational and business performance of the companies. The lean practices considered in the study are Just-In-Time, Total Quality Management, Total Preventive Maintenance, and Human Resource Management. Based on the survey results from 86 managers having lean implementation experience in their companies, this study has revealed that total preventive maintenance and total quality management are the most established lean manufacturing practices in the food sector in Sri Lanka. However, JIT and human resource management are also practiced at levels higher than the average.

The results of the path analysis performed in the study indicate that lean manufacturing practices contribute significantly to all the dimensions of operational performance, namely, quality inventory minimization, delivery, productivity, and cost reduction. According to the results related to the effects on individual performance aspects, it can be concluded that lean manufacturing mostly leads to increased quality, and reduced costs and inventories. The correlations between the individual lean manufacturing practices and the performance dimensions suggest that human resource management, and total preventive maintenance 
are the practices that have the strongest positive relationships with cost, quality and inventory minimization.

With empirical evidence from Sri Lankan food manufacturing industry, this research confirms that operational performance partially mediates the relationship between lean manufacturing practices and business performance. Therefore, lean manufacturing practices directly and indirectly helps improving all three dimensions of business performance, namely, profitability, sales and customer satisfaction. Compared to other lean practices, total preventive maintenance has the highest correlation with all business performance aspects indicting its importance in achieving a firm's competitive advantage. Just-in-time is not highly correlated to many performance dimensions however, helps significantly to increase the customer satisfaction.

\section{THEORETICAL AND MANAGERIAL IMPLICATIONS}

Developing a more informative new construct for representing the extent of practicing lean manufacturing is the major theoretical contribution of this research. Using partial least square structural equation modelling approach, this study developed and validated the new construct as a second-order latent construct of four lean practices: JIT, TQM, TPM, and HRM that have been individually or partially addressed in prior research. Furthermore, the findings of this study add to the current literature by providing empirical evidence for the impact of lean manufacturing practices on operational and business performance, from Sri Lankan food sector. As the study revealed, lean manufacturing has a significant direct and indirect positive impact on business performance where operational performance acts as a mediator.

The study provides several important implications for managers, particularly in the food manufacturing sector. Total preventive maintenance has been identified as the most successful lean practice in many food manufacturing companies in Sri Lanka while emphasizing the usefulness of the other practices that also significantly contribute to high levels of business performance. As implied by the revealed positive relationship between lean manufacturing practices and operational performance, timely maintenance of machines, implementing systematic quality programmes, and better empowerment of people leads to low costs as well as high quality in products, ensuring sustainability. Thus, people who are actively involved in manufacturing operations have better ability to identify problems in the manufacturing system and their suggestions would offer more feasible solutions to the quality issues. Furthermore, replacing broken down parts of machines or installing new machines and training employees on them disturbs the smooth flow of production and hence can increase costs.

Lean manufacturing practices help to enhance sales performance and profitability by increasing quality, speed, and productivity, through the increased product quality, responsiveness, and reduced delivery time. Due to the nature of products, on-time receipt of raw materials and ordering them in small quantities as they are needed are really important factors in satisfying customers in the food manufacturing sector. Systematic quality management programmes, preventive maintenance of plants and equipment, and better management of human resources are vital for ensuring higher profits. As lean offers many economic and environmental benefits, the companies that practice lean strategies in their manufacturing and supply chain operations can stay competitive in today's marketplace while achieving sustainability.

\section{REFERENCES}

Amos, Nneoma Benita, Ariguzo, Vivian Adaobi, Egwakhe, Ashiemamho Johnson, \& Abiodun, Abolaji Joachim. (2020). Lean manufacturing and production efficiency of the food and beverages sector in Nigeria. International Journal of Advanced Operations Management, 12(4), 330-350.

Bevilacqua, Maurizio, Ciarapica, Filippo Emanuele, \& De Sanctis, Ilaria. (2017). Relationships between Italian companies' operational characteristics and business growth in high and low lean performers. Journal of Manufacturing Technology Management, 28(2), 250-274.

Bhamu, Jaiprakash, \& Singh Sangwan, Kuldip. (2014). Lean manufacturing: literature review and research issues. International Journal of Operations \& Production Management, 34(7), 876-940.

Bhutta, M Khurrum S, Egilmez, Gokhan, Chatha, Kamran A, \& Huq, Faizul. (2017). Survey of Lean management practices in Pakistani industrial sectors. International Journal of Services and Operations Management, 28(3), 309-334.

Chauhan, Gulshan, \& Singh, TP. (2012). Measuring parameters of lean manufacturing realization. Measuring Business Excellence, 16(3), 5771.

Chavez, Roberto, Gimenez, Cristina, Fynes, Brian, Wiengarten, Frank, \& Yu, Wantao. (2013). Internal lean practices and operational performance: The contingency perspective of industry clockspeed. International Journal of Operations \& Production Management, 33(5), 562-588.

Dal Pont, Giorgia, Furlan, Andrea, \& Vinelli, Andrea. (2008). Interrelationships among lean bundles and their effects on operational performance. Operations Management Research, 1(2), 150-158.

Dora, Manoj, Van Goubergen, Dirk, Kumar, Maneesh, Molnar, Adrienn, \& Gellynck, Xavier. (2014). Application of lean practices in small and medium-sized food enterprises. British Food Journal, 116(1), 125141.

Hair, Joe F, Ringle, Christian M, \& Sarstedt, Marko. (2011). PLS-SEM: Indeed a silver bullet. Journal of Marketing Theory and Practice, 19(2), 139-152.

Hernandez-Matias, Juan Carlos, Ocampo, Jared R, Hidalgo, Antonio, \& Vizan, Antonio. (2019). Lean manufacturing and operational performance. Journal of Manufacturing Technology Management.

. Industry Capability Report - Food and Beverage Sector. (2017). Export Development Board.

Nawanir, Gusman, Kong Teong, Lim, \& Norezam Othman, Siti. (2013). Impact of lean practices on operations performance and business performance: some evidence from Indonesian manufacturing companies. Journal of Manufacturing Technology Management, 24(7), 1019-1050.

Nawanir, Gusman, Lim, Kong Teong, \& Othman, Siti Norezam. (2016). Lean manufacturing practices in Indonesian manufacturing firms: are there business performance effects? International Journal of Lean Six Sigma, 7(2), 149-170.

Nordin, Norani, Deros, Baba Md, \& Wahab, Dzuraidah Abd. (2010). A survey on lean manufacturing implementation in Malaysian automotive industry. International Journal of Innovation, Management and Technology, 1(4), 374.

Perera, HSC, \& Kulasooriya, DMA. (2011). Lean manufacturing: A case study of a Sri Lankan manufacturing organization. South Asian Journal of Management, 18(1), 149-158.

Rahman, Shams, Laosirihongthong, Tritos, \& Sohal, Amrik S. (2010). Impact of lean strategy on operational performance: a study of Thai manufacturing companies. Journal of manufacturing technology management.

Ripley, Robert E, \& Ripley, Marie J. (1992). Empowerment, the cornerstone of quality: Empowering management in innovative organizations in the 1990s. Management decision, 30(4).

Singh, MP, Meena, Ramphool, \& Panwar, Avinash. (2016). A Survey on the Adoption of Lean Practices in Indian Manufacturing Sector. International Journal of Industrial Engineering, 7(2), 52-62.

White, Richard E, \& Pearson, John N. (2001). JIT, system integration and customer service. International Journal of Physical Distribution \& Logistics Management, 31(5), 313-333.

Wickramasinghe, GLD, \& Wickramasinghe, Vathsala. (2017). Implementation of lean production practices and manufacturing 
performance: the role of lean duration. Journal of Manufacturing Technology Management, 28(4), 531-550.
Yang Ma Ga Mark, Hong, Paul, \& Modi, Sachin B. (2011). Impact of lean manufacturing and environmental management on business performance: An empirical study of manufacturing firms. International Journal of Production Economics, 129(2), 251-261.

\section{APPENDIX}

Operationalization of the Model Constructs

\begin{tabular}{|c|c|c|}
\hline Construct & Sub-construct (Source) & Questionnaire items \\
\hline \multirow[t]{4}{*}{$\begin{array}{l}\text { Lean Manufactur- } \\
\text { ing Practices }\end{array}$} & $\begin{array}{l}\text { Just-In-Time (JIT) (Chavez et al., } \\
\text { 2013; Nawanir et al., 2013; Yang } \\
\text { et al., 2011) }\end{array}$ & $\begin{array}{l}\text { We are aggressively working to lower set up time in our plant. } \\
\text { We have low setup times of equipment in our plant. } \\
\text { Suppliers are directly involved in the new product development process. } \\
\text { Our key suppliers deliver to the plant on a JIT basis. }\end{array}$ \\
\hline & $\begin{array}{l}\text { Total Quality Management (TQM) } \\
\text { (Dal Pont et al., 2008; Nawanir et } \\
\text { al., 2013; Yang et al., 2011) }\end{array}$ & $\begin{array}{l}\text { Waiting time for materials at workstations is very low. } \\
\text { Every place in the organization is neat and well arranged. } \\
\text { The components produced by us meets the international standards. } \\
\text { Department level meetings are held regularly to solve problems. } \\
\text { Whenever a problem occurs, the root cause is identified and solved. } \\
\text { Most of the materials received from suppliers are delivered at point of use. } \\
\text { We always compare our self with competitors. }\end{array}$ \\
\hline & $\begin{array}{l}\text { Total Preventive Maintenance } \\
\text { (TPM) (Nawanir et al., 2013) }\end{array}$ & $\begin{array}{l}\text { Our equipment is in a high state of readiness for production at all times. } \\
\text { Records of routine maintenance are kept. } \\
\text { We scrupulously clean equipment, tools, workspaces, and machines to } \\
\text { make unusual occurrences more noticeable. } \\
\text { We dedicate a periodic inspection and maintenance system to keep ma- } \\
\text { chines in operation. } \\
\text { We dedicate a system of daily maintenance, periodic inspection, and pre- } \\
\text { ventive repairs designed to reduce the probability of machine breakdown. }\end{array}$ \\
\hline & $\begin{array}{l}\text { Human Resources Management } \\
\text { (HRM) (Dal Pont et al., 2008; Her- } \\
\text { nandez-Matias et al., 2019; Yang } \\
\text { et al., 2011) }\end{array}$ & $\begin{array}{l}\text { Employee involvement is implemented. } \\
\text { Department problems are solved as a team exercise. } \\
\text { Employees are rewarded whenever an improvement is made. } \\
\text { At least } 25 \% \text { of the employees' suggestions are implemented. } \\
\text { At least } 60 \% \text { of the employees have attended training programs. }\end{array}$ \\
\hline \multirow[t]{5}{*}{$\begin{array}{l}\text { Operational Per- } \\
\text { formance (Chavez } \\
\text { et al., 2013; Na- } \\
\text { wanir et al., 2013) }\end{array}$} & Quality & $\begin{array}{l}\text { Products that do not meet the quality specifications have been reduced. } \\
\text { We have superior quality of products compared to our competitors'. } \\
\text { Activities in fixing defective products to conform to the quality specifica- } \\
\text { tions (recycle) have been reduced. } \\
\text { Poor quality products that must be discarded (scraps) have been reduced. } \\
\text { The percentage of product that passes final inspection the first time (first- } \\
\text { pass quality yield) has increased. } \\
\text { We have superior quality of service compared to our competitors. }\end{array}$ \\
\hline & Inventory Minimization & $\begin{array}{l}\text { Inventory turnover has increased. } \\
\text { The finished goods inventory level has been reduced. } \\
\text { The raw material inventory level has been reduced. } \\
\text { The work in process inventory level has been reduced. }\end{array}$ \\
\hline & Delivery & $\begin{array}{l}\text { Our ability to deliver products to the market quickly has increased. } \\
\text { Our ability to deliver products to the customer as promised has increased. } \\
\text { We are capable of delivering products to the market faster than our com- } \\
\text { petitors. }\end{array}$ \\
\hline & Productivity & $\begin{array}{l}\text { Labour productivity has increased. } \\
\text { Machine productivity has increased. } \\
\text { Our labour productivity is higher than that of our competitors } \\
\text { Our machine productivity is higher than that of our competitors. }\end{array}$ \\
\hline & Cost Reduction & $\begin{array}{l}\text { Unit manufacturing cost has been reduced. } \\
\text { Our unit manufacturing cost is lower than that of our competitors. } \\
\text { Internal failure costs (i.e. defect, scrap, rework, process failure, price reduc- } \\
\text { tion, and downtime) have been reduced. } \\
\text { External failure costs (i.e. complaints, returns, warranty claims, liability, and } \\
\text { lost sales) have been reduced }\end{array}$ \\
\hline \multirow[t]{3}{*}{$\begin{array}{l}\text { Business Perfor- } \\
\text { mance (Nawanir } \\
\text { et al., 2013; Na- } \\
\text { wanir et al., 2016) }\end{array}$} & Profitability & $\begin{array}{l}\text { Profit margin has increased. } \\
\text { Our return on investment reflects sound investments. } \\
\text { Our profitability has exceeded our competitors'. } \\
\text { Our revenue growth rate has exceeded our competitors'. }\end{array}$ \\
\hline & Sales & $\begin{array}{l}\text { Market share has increased. } \\
\text { Our sales (in rupees) growth has been outstanding. } \\
\text { Our market share growth has exceeded our competitors'. }\end{array}$ \\
\hline & Customer Satisfaction & $\begin{array}{l}\text { Market share has increased. } \\
\text { Our sales (in rupees) growth has been outstanding. } \\
\text { Our market share growth has exceeded our competitors'. }\end{array}$ \\
\hline
\end{tabular}

